\title{
Crossing International Boundaries through Doctoral Partnerships: Learnings from a Chinese- Australian Forum
}

\author{
Matthew Flynn \\ Well Grounded Consultancy, Brisbane, Australia
}

matt@wellgrounded.com.au

\author{
Merilyn Carter, Jennifer Alford, and Hilary Hughes \\ Faculty of Education, Queensland University of Technology \\ (QUT), Brisbane, Australia
}

merilyn.carter@qut.edu.au; jh.alford@qut.edu.au;

h.hughes@qut.edu.au

Jillian Fox

Faculty of Education, Australian Catholic University, Brisbane, Australia

illian.fox@acu.edu.au

Jennifer Duke

Faculty of Education, Queensland University of Technology (QUT), Brisbane, Australia

jk.duke@qut.edu.au

\begin{abstract}
Material published as part of this publication, either on-line or in print, is copyrighted by the Informing Science Institute. Permission to make digital or paper copy of part or all of these works for personal or classroom use is granted without fee provided that the copies are not made or distributed for profit or commercial advantage AND that copies 1) bear this notice in full and 2) give the full citation on the first page. It is permissible to abstract these works so long as credit is given. To copy in all other cases or to republish or to post on a server or to redistribute to lists requires specific permission and payment of a fee. Contact Publisher@InformingScience.org to request redistribution permission.
\end{abstract}

International forums for doctoral students offer a fertile context for developing strategic partnerships between higher education institutions, as well as for building the intercultural capacity of early career academics. However, there is limited research investigating the benefits of international doctoral forum partnerships. This paper presents learnings from a recent international doc-

toral forum held in Beijing, China and attended by doctoral students and academics from Beijing Normal University (China) and Queensland University of Technology (Australia). Drawing on qualitative case study method and a model of boundary crossing mechanisms, we identify the beneficial outcomes of the forum. We describe how the forum arose from a strong ongoing partnership between the Education Fac- 
ulties of Beijing Normal University and Queensland University of Technology. We then identify how, at the institutional and individual level, international doctoral forum participants can be challenged and benefit in four areas: collaboration, intercultural capacity, academic enhancement and program development. Implications for engaging successfully in international doctoral forum partnerships are also discussed.

Keywords: Australia, China, international, doctoral forum, boundary crossing, collaboration, university, case study

\section{Introduction}

International doctoral forums offer partnership building opportunities for universities and their emergent researchers. For participants, international doctoral forums involve various forms of boundary crossing, including physical, intellectual, inter-personal and inter-cultural. This process can be both challenging and beneficial.

International collaboration across education spaces, including higher degree research, is generating considerable interest globally for its capacity-building potential. For the Australian government, educational engagement with other countries in Asia and the Indo Pacific region is a key priority. For example, a recent government initiative, entitled 'The New Colombo Plan' (http://dfat.gov.au/people-to-people/new-colombo-plan/pages/new-colombo-plan.aspx), encourages Australian university students to spend part of their time studying at universities in Asia and the Pacific.

In the past decade, many Australian universities have developed formal partnerships with educational institutions in the People's Republic of China. These partnerships present challenges - and opportunities - to ensure the educational success of such programs, whilst engaging with the local Chinese context. A similar challenge for the Chinese partner institutions is how to incorporate Western approaches and apply them to the Chinese context while maintaining Chinese cultural identity (Yang \& Silver, 2011). A substantial body of literature exists on globalization in higher education exploring competition, economic and political forces, market steering, trans-national education and knowledge transfer (Altbach \& Knight, 2006; Oplatka \& Hemsley-Brown, 2010), and internationalization of higher education, which is often discussed in relation to physical mobility, academic cooperation, intercultural dimensions of teaching and research, and international education (Childress, 2009; Knobel, Simoes \& Henrique de Brito Cruz, 2013). However, there is a lack of knowledge or literature that considers the nature and benefits of international doctoral forum partnerships in general and, in particular, from an individual and an institutional perspective. Responding to this research gap, this case study explores participants' experience of a recent international doctoral forum involving students from an Australian University, Queensland University of Technology (QUT) and a Chinese University, Beijing Normal University (BNU). This case was unique as the doctoral forum's expressed purpose was to enable purposeful and sustained collaboration between students. This contrasted with most doctoral forums that are conducted during larger discipline conferences where time is given for students to hear about each other's research. In addition to sharing research, this case included a collaborative writing task, demonstrating sustained "collectivity and connectivity" that is an important coping mechanism for doctoral students within and beyond the forum (Byers et. al, 2014, p. 126). The study addressed two exploratory research questions:

1. What boundaries do participants cross when engaging in an international doctoral forum?

2. What benefits does an international doctoral forum partnerships produce for participants and their universities? 
Flynn, Carter, Alford, Hughes, Fox, \& Duke

In answering these questions, we adopted Akkerman and Bakker's (2011) four boundary crossing mechanisms as a theoretical framework to provide a basis for a qualitative case study of the QUTBNU doctoral form conducted in Beijing in 2013.

In this paper, we begin by outlining the international doctoral forum partnership established between BNU and QUT. This is followed by a brief literature review that discusses the boundary crossing model that frames this study and the intercultural learning dimension that is essential to successful collaboration within international higher education. We then present the methodology used and the study's findings. We conclude with a discussion of key implications for future international doctoral forums.

\section{Forum Background}

Since 2007, the Faculties of Education at both the QUT and BNU have cooperated in organizing an annual doctoral forum that is hosted in alternate years in Brisbane, Australia and Beijing, China. Over these seven years a relationship has been built at the individual and institutional level. Foundations have been laid for ongoing academic dialogue and long-term collegial relationships and research partnerships between the universities. As an indication of the increasing potential of the partnership, the 2012 forum achieved a publication co-authored by all Australian and Chinese participants (Mu et al., 2013). The 2013 forum advanced this collaborative tradition with the development of two publications, this case study and a Bourdieusian analysis of relationships within the forum (Mu et al., in press).

\section{Crossing Boundaries: Conceptual Frame}

The concept 'boundary crossing' involves traversing the gap between two disparate organizations such as a Chinese and an Australian university. Boundary crossing was characterized by Engeström, Engeström, and Kärkkäinen (1995) as "horizontal expertise where practitioners must move across boundaries to seek and give help, to find information and tools wherever they happen to be available" (p. 332). Thus, boundary crossing is a means for partner organizations to interact and improve compatibility for functioning in the other setting (Akkerman \& Bakker, 2011; Star \& Griesemer, 1989). A shared vision is established and mutual benefits for the partnership are identified (Billet, 2002; Billet, Ovens, Clemans, \& Seddon, 2007; Lave \& Wenger, 1991; Pillay, Watters, \& Hoff, 2013).

As a concept, boundary crossing has been applied broadly to educational research projects: for instance, in (a) organizational systems and structures of universities and associated workintegrated learning programs (Kjellen, 2010); (b) teaching out-of-field when teachers are not qualified to teach, for example, mathematics (Hobbs, 2012); (c) career change professionals entering the teaching workforce (Watters \& Diezmann, 2012); and (d) industry-school partnerships (Flynn, Pillay, \& Watters, 2014). The notion of boundary crossing is particularly relevant to this study as the primary purpose of international doctoral forum partnerships is to facilitate doctoral student professional development, with outcomes such as co-produced publications, intercultural competence and compatibility for future international academic work.

Morse's (2010) research on how partnerships create public benefit formed through collaboration across jurisdictional boundaries is useful in unpacking the concept of boundary crossing for international doctoral forums. Stakeholder organizations, such as universities, are described as structural catalysts that enable collaboration and the formation of partnerships. They have the capacity to hasten change by facilitating connections between potential partners. They also enable the convergence of multiple perspectives because of their pre-existing connections. For instance, in the context of the present paper, the BNU-QUT doctoral forum partnership is potentially a structural catalyst for other initiatives between QUT and BNU. 
Common characteristics associated with an organization's boundary crossing processes include "accountability to both sides of the boundary; the use of boundary objects such as maps, reports, and forecasts that are co-produced by actors on different sides of the boundary; participation across boundary; convening; translation; coordination and complementary expertise; and mediation" (Cash et al., 2006, pp. 8-9). These characteristics are grouped into two domains, strategic and operational. For example, a partnership between two universities can be clarified and formalized in a memorandum of understanding - a strategic boundary crossing characteristic. An example of an operational boundary crossing characteristic is the convening of meetings between project managers of the respective universities.

Whilst Cash et al., (2006) detailed strategic and operational characteristics, they have not elaborated on how they manifest as processes across organizational boundaries. However, Akkerman and Bakker (2011), through an extensive literature review, identified four boundary crossing mechanisms that address matters of process: Identification, Coordination, Reflection and Transformation (see Figure 1).

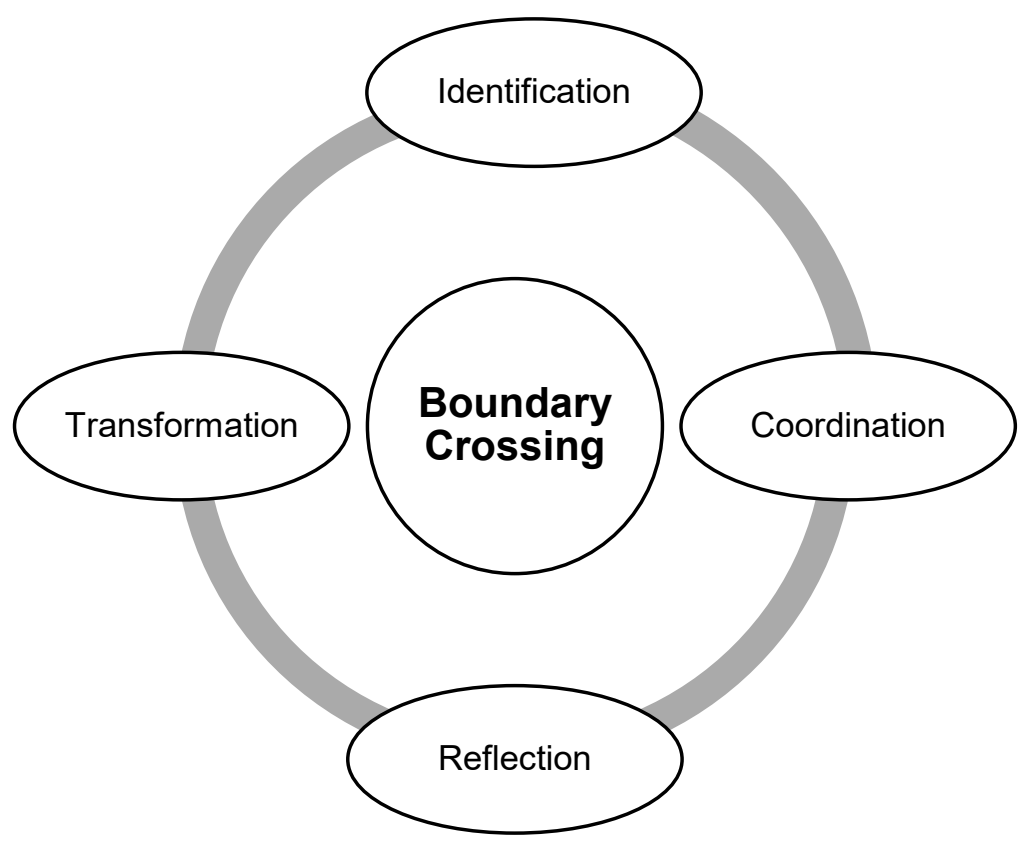

Figure 1. Four boundary crossing mechanisms (Akkerman \& Bakker, 2011).

Akkerman and Bakker's four boundary crossing mechanisms can be explained as follows.

\section{Identification}

This is a process of delineating the differences and similarities between two partners. Basic questions are asked of partners, such as "Who are you?", "What do you do?", and "How do you contribute to the partnership?" With regard to the international doctoral forum partnership, learning about the specific activities in both universities (BNU-QUT) is important at the individual and institutional level. For instance, a doctoral student would benefit from identifying and assessing their personal intercultural capacity prior to participating in an international doctoral forum. At the institutional level, there needs to be an appreciation of the aims and objectives of the respective participating universities. 
Flynn, Carter, Alford, Hughes, Fox, \& Duke

\section{Coordination}

This is where repeated interactions between the partners facilitate the permeation of boundaries between them. In the context of an international doctoral forum, repeated coordinating interactions can occur between participating universities through the exchange of information, for instance, the coordination of travel and accommodation arrangements, the establishment of the doctoral forum agenda, and the co-production of papers for journal publication. Clearly articulating the activities and constraints of both partners advances the international doctoral forum partnership.

\section{Reflection}

The Akkerman and Bakker (2011) model includes reflection as an element to facilitate participants' "coming to realize and explicate differences between practices and thus to learn something new about their own and other's practices" (p. 145). For an international doctoral forum, the reflective process is clearly an important element in the course of boundary crossing to expand perspectives and potentially enrich the development of the participants. However, while Akkerman and Bakker (2011) state that "the explication and visibility of perspectives" (p. 151) is necessary, they do not provide details of how this reflective work might be carried out. Therefore, we adopted a four step reflective writing procedure developed from the work of Bain, Ballantyne, Mills, and Lester (2002). According to Ryan (2011), the levels in this model "increase in complexity and move from description of, and personal response to, an issue or situation; to the use of theory and experience to explain, interrogate, and ultimately transform practice" (p. 3). A purposeful procedure such as this enables all participants to reflect individually and deeply, and is underpinned by a view of knowledge as transformative rather than transmissive (Ryan, 2011).

\section{Transformation}

Finally, transformation occurs progressively as an outcome of the other boundary crossing mechanisms. That is, as a participant identifies activities, establishes systems to coordinate activities, and reflects on the perspectives of the other participants, there will likely be genuine transformation or some change in current practices that leads to improved partnership outcomes. For an international doctoral forum partnership, that might involve changing the forum approach from less emphasis on formal presentations to a focus on critical discussion and collaborative writing.

The authors have adopted Akkerman and Bakker's (2011) boundary crossing mechanisms as framework for responding to the research questions by exploring international doctoral forum partnerships and how mechanisms were conceptualized for this case study of the BNU-QUT international doctoral forum.

\section{The Intercultural Dimension}

Intercultural understanding is essential to any successful international engagement, including international doctoral forum partnerships. Higher education promotes intercultural understanding as a measure of university graduate capability (Leask, 2002; Stone, 2006). Various conceptualizations of intercultural understanding are evident in the literature, for example, "intercultural competence" (Crichton \& Scarino, 2007) and "intercultural literacy" (Heyward, 2002) but these do not always align. It is an abstract concept that requires definition in order to determine whether it has been attained; however, there is some disagreement on that definition (Deardorff, 2006). For the purpose of this study, a broad view of intercultural understanding was adopted: "the abilities to behave and communicate effectively and appropriately in multicultural contexts" (Deardorff, 2006, p. 247). This is an ongoing process, involving interpretation, negotiation, and the ability to self-reflect, leading to transformation of knowledge, attitudes, and skills towards cultural differ- 
ence. Fluency in a common language is central to this process, as it provides the principal tool for interaction and communication (Deardorff, 2006). In addition, Hunter, White, \& Godley (2006) suggest that a key indicator is being open-minded when seeking to understand others' cultural practices and expectations, "leveraging this gained knowledge to interact, communicate and work effectively outside one's environment" (pp. 130-131). Of particular relevance to this paper is Leask's (2002) assertion that developing international perspectives among higher education students is dependent on alignment between projected graduate qualities and teaching and learning opportunities provided for students. The BNU-QUT doctoral forum provided such opportunity, and this paper reports on the intercultural capacity outcomes of the doctoral forum held in 2013.

\section{Context: 2013 BNU-QUT forum and participants}

The 2013 BNU-QUT forum was hosted by the Education Faculty of Beijing Normal University. It comprised twelve participants (summarized in Table 1) with an equal number from BNU and QUT. All the doctoral students were undertaking PhDs. Both groups were led by an academic staff member, who collaboratively liaised with faculty leadership, oversaw the organization of the whole forum, and acted as student mentors. The intense ten day program included formal presentations, workshops, two formal dinners, many other shared meals, and visits to local schools and cultural sites. The program ensured sustained close interaction between all forum members. Formal sessions and social exchanges were conducted in English. The Chinese students acted as guides and interpreters for the Australians in negotiating the culturally less familiar environment of Beijing.

Table 1. Overview of BNU-QUT forum participants

\begin{tabular}{|c|c|c|}
\hline & QUT & BNU \\
\hline Academic status & $\begin{array}{l}6 \text { forum members: } \\
\text { - } 2 \text { academic mentors (including } \\
\text { the QUT group leader) } \\
\text { - } 4 \text { doctoral students }\end{array}$ & $\begin{array}{l}6 \text { forum members: } \\
\text { - } 1 \text { academic mentor (BNU } \\
\text { group leader) } \\
\text { - } 5 \text { doctoral students }\end{array}$ \\
\hline Age range & $35-60$ & $26-40$ \\
\hline Gender & $\begin{array}{l}5 \text { female } \\
1 \text { male (doctoral student) }\end{array}$ & $\begin{array}{l}5 \text { female } \\
1 \text { male (academic mentor) }\end{array}$ \\
\hline
\end{tabular}

A third QUT academic, who was in Beijing at the time of the forum for other purposes, was involved in some sessions of the doctoral forum but did not participate in this research.

\section{Methodology}

Given the exploratory nature of the research questions, a case study design was selected. Case studies apply ethnographic methods to the study of particular phenomena (Hammersley \& Atkinson, 2007). This section provides details of the methods used and the limitations of the study.

\section{Methods}

This qualitative case study (Simons, 2009; Stake, 1995) investigated the nature and outcomes of the 2013 QUT-Beijing Normal University doctoral forum, which comprised nine doctoral students and three supervising academics. In particular it sought insights about the boundaries that participants crossed when engaging in the BNU-QUT forum and indications of the benefits for participants and their universities. 
The research was designed and conducted by the six Australian members of the doctoral forum. We sought to explore real life experiences of the international doctoral forum from the participants' varied perspectives (Denzin \& Lincoln, 2005). The qualitative case study approach enabled us to explore the "complexity and uniqueness" of the participants' experience (Simons, 2009, p. 21). As co-researchers and forum participants we engaged in a reflective research process, documented multiple perspectives, and represented our differing interests and values (Simons, 2009, p. 23).

Prior to the forum, the QUT researchers designed the study, gained ethical clearance, and sent information to BNU counterparts. As all twelve forum members consented, the research participants included nine doctoral students (five from BNU and four from QUT) and three academics (one from BNU and two QUT). We collected data from two documentary sources, a questionnaire and free-text responses. This four-way data triangulation captured multiple perspectives on the forum. The documentary sources were an email from the Research Manager of the Office of Education Research at QUT outlining QUT's objectives in participating in the forum and information about the organization of the doctoral forum from the official program. The twelve participants completed the questionnaire on the last day of the forum. It sought their views about the nature of their boundary crossing and benefits of the forum to their university. A copy of the questionnaire is provided in the Appendix. The written responses were QUT participants' feedback to their university on return to Australia.

Analysis of the documentary, questionnaire, and feedback data followed a similar pattern. In line with the research questions, the focus was on (a) identifying the boundaries that the participants crossed when engaging in the international doctoral forum and (b) what benefits the forum produced for the participants and their two universities. We applied standard qualitative thematic analysis methods (Saldana, 2013). First, two researchers undertook a priori coding supported by meaningful journalistic notes (Layder, 1998). On completion, the coding was independently reviewed and verified by a third researcher. We then collaboratively reviewed the coded data to identify similarities and differences, gradually sorting it into broad thematic categories (summarized in Table 2). To identify and interpret the wider implications for international doctoral forum partnerships, the key themes were aligned progressively with the four boundary crossing mechanisms discussed previously (Akkerman \& Bakker, 2011).

Table 2. Thematic categories.

\begin{tabular}{lc}
\hline Title & Frequency \\
\hline Boundaries & 49 \\
Pre, during and post forum collaboration & 41 \\
Program development and management & 40 \\
Intercultural capacity & 30 \\
Scholarly knowledge sharing and building & 23 \\
Resources & 23 \\
Roles and responsibilities & 20 \\
Innovation & 15 \\
Academic writing process and product & 11 \\
University aims and objectives & 7 \\
Impact of forum on individual academic trajectory & 6 \\
Merit-based selection process & 4 \\
\hline
\end{tabular}


The systematic analysis revealed four ways in which the BNU-QUT doctoral forum participants crossed boundaries and four associated benefits. These findings are outlined in the following case study report.

\section{Limitations}

A small-scale exploratory study such as this has limitations. The findings are intended to be indicative rather than generalizable. Given the relatively small participant group, statistical analysis was not appropriate. Although the BNU-QUT doctoral forum partnership has existed since 2007, this study only considers the 2013 forum. Further, as the researchers are all from QUT and have an Australian viewpoint, the findings may not fully represent the experience of their Chinese counterparts. However, the findings draw upon data that reflect the first-hand perspectives of both the QUT and BNU participants. Thus, the case study offers productive insights that increase understanding about the potential benefits of international doctoral forums, provides recommendations for developing future partnerships between universities, and lays the foundation for future research about the experiences and outcomes of future international doctoral forum partnerships.

\section{Findings}

In the context of the two exploratory research questions about international doctoral forums that focus on the boundaries the participants crossed and the benefits of such a forum for individuals and universities, this section presents the key findings of the case study of the 2013 BNU-QUT doctoral forum. Extracts from questionnaire responses in this section are assigned codes, a ' $\mathrm{B}$ ' for $\mathrm{BNU}$ or a ' $\mathrm{Q}$ ' for QUT, and a number representing a specific question from the questionnaire (for example, 'Q3' or 'B2').

\section{Boundaries}

The participants identified a variety of boundaries encountered in the BNU-QUT doctoral forum. The questionnaire was developed from the four boundary crossing mechanisms, and asked two specific questions about the types of boundaries crossed during the forum. As expected, the participants identified several boundaries each, 49 in total. These boundaries were distilled into five types, namely, political, academic, educational systems, cultural, and geographical. A number of barriers, approximately half of which were cultural, were identified by both QUT and BNU students. For example, feedback from two QUT students after the forum highlighted the need for greater understanding about cultural Confucian philosophies and values and how they underpin education. Another QUT student experienced a barrier in "becoming familiar with the Chinese way of doing things" (Q5).

All of the BNU students commented on the English language challenges they faced during the forum when listening, speaking and writing. Participant B6 stated "at the beginning of the forum I felt shy to speak English and couldn't remember more words". She also commented "I am crossing boundaries in language...", suggesting that they were leveraging their growing knowledge (Hunter et al., 2006) of seminar practices in Standard Australian English in order to interact effectively. There were times, however, when this was too big a challenge: "Language, I can't understand what they are speaking totally, about $50 \%$ is missed" (B6). Feedback from a QUT student after the forum recommended that some Chinese language lessons be offered to the participants prior to departure to provide some foundational knowledge of the Chinese language.

\section{Benefits}

The responses of the participants showed that the BNU-QUT doctoral forum produced four major benefits associated with international collaboration, intercultural understanding, academic capaci- 
ty, and doctoral program development (see Figure 2). These findings align with the boundary crossing mechanisms, presented earlier in this paper, and apply at the individual and institutional level.

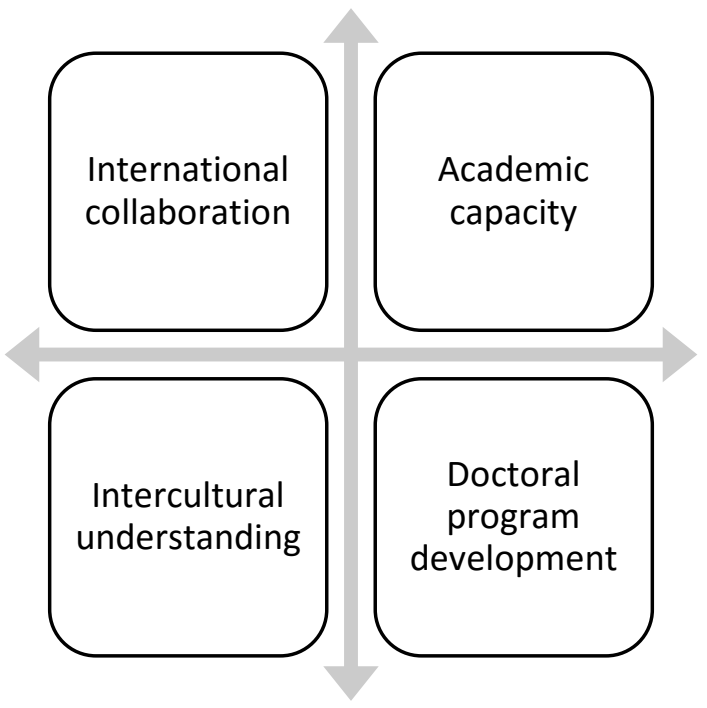

Figure 2. Four major benefits of the BNU-QUT doctoral forum

\section{International collaboration}

Of the four benefits in Figure 2, collaboration was found to be most dominant (mentioned 41 times in questionnaire responses). This finding applied to both the institutional and individual levels of the partnership. For instance, when asked about their university's expectations from the forum, participants frequently mentioned collaborative practices:

My university expects me to strengthen the mutual relationship and sincere friendship already established (B1).

My university expects me to build partnerships with international colleagues (Q1).

Feedback from all QUT participants after the forum indicated that a significant highlight of the week-long collaboration was the building of relationships. One comment indicated the new relationships established with students will be long term: "I have developed a great respect for the group and found common interests with each member...theirs was true collegial support."

At the individual level, the data were equally compelling. The majority of responses to a question about the types of boundaries participants crossed during the forum were also indicative of collaboration benefits. For instance:

I have personally established friendships with Chinese students and staff and closer bonds with QUT colleagues (Q5).

I crossed the friendship boundary, making lots of good friends (B5).

Collaboration was often assisted by the participants' reflections, particularly clarifying similarities and differences between BNU-QUT, and in learning something new about their own and other's practices. Reflection on the forum went beyond personal observation of an issue or situation. For instance, one participant described how the forum experience helped them to understand similarities between BNU and QUT: "Both universities want to extend higher degree research 
student experience and create collaborative opportunities to build international partnerships" (Q9).

The opportunity for collaborative writing that sustained the connection between the universities was another important benefit to arise through the BNU-QUT doctoral forum. This was especially significant for the Chinese students, for whom publication in an English language journal is a major academic achievement in itself. This brings their work to a wider international audience, thus crossing further cultural and academic boundaries. Moreover, the Australian cohort benefitted from their experience as members of a cross cultural writing and editing team. The doctoral forum resulted in the development of two papers for future publication: a paper about negotiating power relations in an international doctoral forum jointly prepared by all of the QUT and BNU forum participants, planned at the forum and drafted collaboratively after the forum (Mu et al., in press); and this paper prepared after the doctoral forum by the QUT participants.

\section{Intercultural understanding}

Participation in the BNU-QUT forum was found to be an ideal context for developing intercultural capacity. This finding was distinguishable as a patterned response within the dataset. To demonstrate, Figure 3 presents eight representative extracts from a total of thirty responses. The development of intercultural awareness and communication skills was evident at both the individual and institutional levels, although the former was more prevalent. Enhanced individual intercultural capacity arguably benefitted both universities. For instance, the acquisition of individual intercultural capacity by doctoral students enabled international activities of value to both institutions, such as collaborative research projects.

\begin{tabular}{|c|c|c|}
\hline $\begin{array}{c}\text { My intercultural capabili- } \\
\text { ties have been strengthened } \\
\text { (Q1) }\end{array}$ & $\begin{array}{c}\text { Doctoral forum helped me } \\
\text { to understand cultural and } \\
\text { language difference (B9) }\end{array}$ & $\begin{array}{c}\text { My university expects me } \\
\text { to form relationship with } \\
\text { English speakers (B1) }\end{array}$ \\
\hline $\begin{array}{c}\text { It's been challenging to } \\
\text { adapt to unfamiliar ways of } \\
\text { doing things (B6) }\end{array}$ & Intercultural benefits & $\begin{array}{c}\text { Both universities contribute } \\
\text { differences in thought, aca- } \\
\text { demic and cultural (Q3) }\end{array}$ \\
\hline $\begin{array}{c}\text { I am crossing boundaries in } \\
\text { language, food and cus- } \\
\text { toms (Q3) }\end{array}$ & $\begin{array}{c}\text { I've learn't [sic] about in- } \\
\text { ternational understanding, } \\
\text { we should respect each } \\
\text { culture (B8) }\end{array}$ & $\begin{array}{c}\text { I have become more famil- } \\
\text { iar with the Chinese way of } \\
\text { doing things (Q5) }\end{array}$ \\
\hline
\end{tabular}

Figure 3. Representative responses on Intercultural Capacity

In practice, the BNU-QUT doctoral forum participants developed intercultural understanding by identifying shared similarities and differences across many areas. For instance, they came to realize that within their doctoral programs in education, the Chinese students typically undertake more quantitative course work, where the Australian students tend to place greater emphasis on theoretical conceptualization.

Reflecting in this way on culturally-related similarities and differences was seen to be beneficial in enabling doctoral students' practice in unfamiliar settings. For example, participants were able to develop new ideas about the transformation of existing or future practice, including a suggestion to establish an "international office, further internationalizing the curriculum, joint projects, study exchanges, showcasing international teaching and learning practice, more international travel for higher degree students, an international summer school program and the promotion of cross-cultural communication and teaching practices" (Q11). 
Flynn, Carter, Alford, Hughes, Fox, \& Duke

\section{Academic capacity}

This study found that the BNU-QUT forum contributed to the objective of developing academic capacity in doctoral students, with 34 responses identifying this benefit. It was most evident in two activities: (a) academic writing tasks $(\mathrm{n}=11)$; and (b) scholarly knowledge sharing $(\mathrm{n}=23)$. At the institutional level, QUT and BNU provided support for the development of academic capacity in forum participants. For example, a QUT student stated, "My university contributed academic support to the international doctoral forum partnership in terms of knowledge, advice and research presentations by professors and lecturing staff" (Q3). Similarly, a BNU student revealed, "My University encourages $\mathrm{PhD}$ candidates to this forum to improve the internationalization of the university and enhance mutual academic communication" (B1). University goals were achieved through the forum, as most students formed academic partnerships, "I'm crossing academic boundaries, establishing research partnerships with BNU colleagues" (Q5). Similarly, BNU students also emphasized how they were benefitting academically through the partnership, "QUT PhD students are different from me because they have more working experiences than those from BNU, therefore shared more knowledge gained from work. Very interesting, I really appreciate that" (B2).

The forum was also a structural catalyst for the academic staff members to cross international boundaries and, thereby, pursue academic activities. In addition to their leadership and mentoring role, they were afforded opportunities to form their own academic partnerships and strengthen existing relationships between the two universities. For instance, one QUT academic, a librarian, formed a new research partnership with a BNU academic librarian. That partnership has since grown into a cross-institutional research project that investigates international students' experiences of the libraries at QUT, BNU, and a university in USA.

\section{Doctoral program development}

Questionnaire responses provided insights about development of the doctoral forum related to the following: (a) achievement of university aims and objectives; (b) the forum program structure; (c) risk management; and (d) basic project coordination of pre- and during forum program activities. Evidently, QUT and BNU participants received similar information prior to the forum about the program activities. For example, both universities spent considerable effort promoting the forum and selecting suitable participants to attend the forum. Aspiring QUT and BNU students and academics addressed similar criteria on the following: knowledge and experience with other cultures; engagement in university/professional communities; benefits derived from participating in the forum; benefits to QUT/BNU; a relevant topic for a presentation at the forum; and evidence of publications and scholarly presentations at conferences. Prior to the forum, there were considerable operational activities to support participants' boundary crossing, including "disseminating information packs to participants, forum program, maps, travel tips and health and safety information" (Q4). This type of information is what Star and Griesemer (1989) call boundary objects. Boundary objects are particularly helpful in facilitating boundary crossing and are enablers for coordinating (coordination mechanism) between organizations. Doctoral students from QUT were also involved in a number of meetings prior to the forum, as cultural preparation and to develop plans for possible publications that may emerge from the forum. Feedback after the forum from the four QUT students commented on their preparedness for the forum. For example, one student stated, "Interactions prior to the forum enabled the QUT cohort to bond as a group then grow into a cohesive, supportive, productive team which contributed to the successful partnership building with the BNU cohort." (Q7).

A QUT academic with previous experience with the BNU-QUT doctoral forums led the QUT group, supporting the students with practical guidance, assisting them to cross boundaries. Feedback suggested that the Australian leader "led the forum capably, affably managing many contin- 
gencies and events" demonstrating "knowledge of Chinese culture." The BNU group leader, a Chinese academic who had previously studied at QUT and been involved in past doctoral forums, "provided a BNU-QUT cultural bridge" (Q4). A boundary crossing relationship such as this is defined by Cash et al., (2006) as complementary expertise. Feedback indicated that the experience and leadership of both academics was critical to the success of the doctoral forum. In particular, the bilingual BNU group leader, with his detailed knowledge of both BNU and QUT, was seen as a fundamental and necessary inclusion. According to a QUT student, "His input was invaluable... he gave us huge amounts of advice and support about cultural and academic issues."

As representatives of the host country, the Chinese doctoral students were afforded additional program responsibilities during the forum. For example, "Chinese students were involved in food preparation and general hospitality - each had a specific job, e.g., accommodation, transport QUT participants to and from airports" (B4).

From an institutional perspective, the BNU-QUT doctoral forum achieved the objectives outlined by the QUT Education Faculty's Manager of Research. They indicated an expectation that the forum contributes towards the strategic priorities of both the university and the Faculty of Education through:

- $\quad$ an annual week long academic program that includes presentations and discussions about educational issues of mutual interest to Australian and Chinese doctoral students;

- development of relationships between students and staff for collaborative research and writing;

- $\quad$ appreciation of the Chinese education system and cultural heritage; and

- $\quad$ promotion of QUT as a site for doctoral study, short courses, research and consultancy (email, QUT Office of Education Manager, Oct 2, 2013).

To summarize, the findings of this qualitative case study, which have been theorized based upon the boundary crossing model (Akkerman \& Bakker, 2011), present a snapshot of a recent international doctoral forum as experienced by a particular group of Australian and Chinese students. In particular, they outline the various ways participants experienced boundary crossing and identify the benefits of this forum for the individuals and their respective universities. The next section discusses their implications for the future development of international doctoral forum partnerships.

\section{Discussion and Recommendations}

This section discusses the implications of the findings of the 2013 BNU-QUT doctoral forum. Whilst the findings are not generalizable to every situation, new understandings arising from this case study allow some informed observations and recommendations for future development of international doctoral forums.

Conducting collaborative research within a cross-cultural team is complex because there are many intercultural boundaries to negotiate. A key contributor to successful boundary crossing is the capacity to recognize and respond to subtle intercultural cues. To this end, the key findings outlined above about the BNU-QUT doctoral forum support recommendations for developing partnerships to promote international doctoral forums. The previously discussed boundary crossing model with its four inter-related mechanisms provides a useful framework for the discussion in this final section. 
Flynn, Carter, Alford, Hughes, Fox, \& Duke

\section{Identification}

The boundaries identified in this research offer suggestions for other students and universities seeking to develop international doctoral forum partnerships. They signal opportunities to pursue and pitfalls to avoid in organizing the forum, as well as provide insights about how to cross related cultural and academic boundaries. In particular, the evidence of the BNU-QUT forum highlights the importance for international doctoral forum planners and participants to identify similarities and differences across their social, cultural, and academic environments and then to build upon this knowledge to co-create supportive and mutually enlightening doctoral partnerships.

Language is closely associated with cultural identity. As a central element in intercultural capacity (Deardorff, 2006), it often represents a major boundary to cross. The BNU selection program required that BNU participants were all fairly fluent English users, but sometimes they lacked confidence to speak in formal or large group settings. In contrast, the QUT participants knew little or no Mandarin. Consequently, from the outset there was an assumption that English would be used throughout the BNU-QUT forum. There was no formal provision for sessions or materials to be translated from Chinese to English, or English to Chinese. While this had practical communication benefits, it also had a potential, if unintended, alienating effect for the Chinese participants despite being within their usual academic environment. In addition, it diminished the Australian participants' learning opportunity to experience linguistic challenges associated with intercultural partnerships. Thus, it seems important for future international doctoral forum partnership organizers to address the implications of privileging a particular language and who does the boundary crossing and who does not.

\section{Coordination}

Planning and organizing a doctoral forum across international boundaries requires effective coordination. The successful implementation and outcomes of the BNU-QUT doctoral forum demonstrate the importance of coordinated planning and organization of all aspects. Careful attention to partnership building between QUT and BNU over several years provided leaders that were experienced in past forums and enabled participants to cross considerable boundaries whilst experiencing minimal adverse impact. This finding indicates the importance of willing collaboration at the individual and institutional levels in developing productive international doctoral forum partnerships.

\section{Reflection}

Reflection can play a vital part in international doctoral forums. As evidenced by this case study, the participants' reflection enables them to develop deep understandings about the nature of boundary crossing and benefits of the program. In particular, personal reflections played an important role in removing barriers and advanced collaboration among forum participants. This finding supports the recommendation to incorporate continuous written and oral reflection before, during, and after a doctoral forum. Through reflection, participants can develop insights that support their growth as researchers and capacity to negotiate cross-cultural collaboration.

\section{Transformation}

Reflection can lead to transformation in a doctoral student's thinking and practice, so enabling academic work in culturally unfamiliar settings. This was demonstrated during the BNU-QUT forum by participants' openness to new ideas and ways of working. Their creative response reflects Deardorff's (2006) assertion that intercultural understanding is an ongoing process of interpreting and reflecting which leads to transformation of knowledge, attitudes and skills. This was 
particularly true for the BNU students whose objective to publish research in an English language journal is being realized through continuing collaboration with their Australian counterparts.

\section{Conclusion}

As demonstrated by this qualitative case study, doctoral students and their universities can derive extensive and ongoing benefits through participation in an international doctoral forum. The success of the BNU-QUT doctoral forum derived in great part from the readiness of forum participants, both doctoral students and academics, to collaborate. This was critical to achieving the aims and objectives of the two partner universities. Arguably, the academic, inter-cultural, and program benefits would not have been realized without this. Equally, the focus on personal reflection, both written and oral, throughout the forum enabled participants to explore and gain understanding about the various boundaries they were crossing. It led to genuine transformation in the participants' intercultural capacity and research practice and further strengthened the partnership between researchers in education at QUT and BNU.

Despite the considerable benefits derived from the BNU-QUT doctoral forum presented in this paper, we acknowledge that it is exploratory, and that further investigation into the strengths and weaknesses of other international doctoral forums are required for deeper explanation. For instance, a study that compares multiple cases (other similar international university doctoral partnerships) may create compelling research. Critical to comparing multiple cases will be the application of a consistent theoretical framework that this paper has presented in the boundary crossing framework. Perhaps a limitation of the boundary crossing framework is that it stops short of identifying and exploiting the productive outcomes of doctoral forums. The present paper has attempted to head in this general direction by asking, "What benefits does an international doctoral forum partnership produce for participants and their universities?"

We also suggest that future international doctoral forums might investigate ways to foster greater mutual exchange of knowledge and practices. A key finding in this paper was that Chinese students generally do more quantitative course work, where the Australian students tend to place greater emphasis on theoretical conceptualization. In the co-production of a future paper we suggest that the BNU students lead and teach the QUT students to adopt a quantitative approach and, in so doing, strengthen the mutually beneficial partnership and offer research that appeals to a wider readership. Research into the language(s) used as the medium of exchange and how this might constrain or enable mutually beneficial outcomes in doctoral forums could also be useful.

\section{References}

Akkerman, S. F., \& Bakker, A. (2011). Boundary crossing and boundary objects. Review of Educational Research, 81(2), 132-169. doi: 10.3102/0034654311404435

Altbach, P., \& Knight, J. (2006). The internationalisation of higher education: Motivation and realities. The NEA Almanac of Higher Education, 2-11.

Bain, J. D., Ballantyne, R., Mills, C., \& Lester, N. C. (2002). Reflecting on practice: Student teachers' perspectives. Flaxton: Post Pressed.

Billett, S. (2002). Transfer and social practice. Australian and New Zealand Journal of Vocational Education Research, 6, 1-25.

Billett, S., Ovens, C., Clemans, A., \& Seddon, T. (2007). Collaborative working and contested practices: Forming, developing and sustaining social partnerships in education. Journal of Education Policy, 22(6), 637-656. doi: 10.1080/02680930701625288

Byers, V. T., Smith, R. N., Hwang, E., Angrove, K. E., Chandler, J, I., Christian, S. H., ... Onwuegbuzie, A. J. (2014). Survival strategies: Doctoral student perceptions of challenges and coping methods. In- 
ternational Journal of Doctoral Studies, 9, 109-131. Retrieved from http://ijds.org/Volume9/IJDSv9p109-136Byers0384.pdf

Cash, D. W., Adger, W. N., Berkes, F., Garden, P., Lebel, L., Olsson, P., \& Young, O. (2006). Scale and cross-scale dynamics: Governance and information in a multilevel world. Ecology and Society, 11(2), 8.

Childress, L. (2009). Internationalisation plans for higher education institutions. Journal of Studies in International Education, 13(3), 289- 301.

Crichton, J., \& Scarino, A. (2007). How are we to understand the 'intercultural dimension'? An examination of the intercultural dimension of internationalisation in the context of higher education in Australia. Australian Review of Applied Linguistics, 30(1), 4.1-4.21.

Deardorff, D. (2006). Identification and assessment of intercultural competence as a student outcome of internationalization. Journal of Studies in International Education, 10(3), 241-266.

Denzin, N., \& Lincoln, Y. (2005). Introduction: The discipline and practice of qualitative research. In N. Denzin, \& Y. Lincoln (Eds.), The Sage handbook of qualitative research (3rd ed., pp.1-32). London: Sage.

Engeström, Y., Engeström, R., \& Kärkkäinen, M. (1995). Polycontextuality and boundary crossing in expert cognition: Learning and problem solving in complex work activities. Learning and Instruction 5(4), 319-336.

Flynn, M. C., Pillay, H., \& Watters, J. (2014). Industry-school partnerships: Boundary crossing to enable school to work transitions. Journal of Education and Work, 1-23. doi: 10.1080/13639080.2014.934789

Hammersley, M., \& Atkinson, P. (2007). Ethnography: Principles in practice. Retrieved from http://QUT.eblib.com.au/patron/FullRecord.aspx?p=308687

Heyward, M. (2002). From international to intercultural: Redefining the international school for a globalised world. Journal of Research in International Education, 1(9), 9-32.

Hobbs, L. (2012). Teaching out-of-field: Factors shaping identities of secondary science and mathematics. Teaching Science, 8(1), 23-31.

Hunter, B., White, G. P., \& Godley, G. C. (2006). What does it mean to be globally competent? Journal of Studies in International Education, 10(3), 267-285.

Knobel, M., Simoes, T. P., \& de Brito Cruz, C. H. (2013). International collaborations between universities: Experiences and best practices. Studies in Higher Education, 38(3), 405-424.

Kjellen, B. (2010). Cases as boundary objects: Transfer and authenticity in work-integrated learning. Journal of Cooperative Education and Internship, 44(2), 26-31.

Lave, J., \& Wengner, E. (1991). Situated learning: Legitimate peripheral participation. US: Cambridge University Press.

Layder, D. (1998). Sociological practice: Linking theory and social research. London: Sage.

Leask, B. (2002). Tying knots or bows? Measuring the development of a generic capability (international perspectives) in students. Paper presented to Evaluations and Assessment Conference, Brisbane, November 14-15, 2002, pp.1-11.

Morse, R. S. (2010). Integrative public leadership: Catalyzing collaboration to create public value. The Leadership Quarterly, 21(2), 231-245.

Mu, G. M., Jia, N., Hu, Y., Hughes, H., Shi, X., Zhang, M.-c., ... Xia, H. (in press). Generating benefits and negotiating power relations in an international doctoral forum: Capital in fields. International Journal of Doctoral Studies.

Mu, G. M., Zheng, X., Jia, N., Li, X., Wang, S., Chen, Y., ... Diezmann, C. (2013). Revisiting educational equity and quality in China through Confucianism, policy, research, and practice. The Australian Educational Researcher, 1-17. doi: 10.1007/s13384-013-0113-0 
Oplatka, I., \& Hemsley-Brown, J. (2010). The globalization and marketization of higher education: Some insights from the standpoint of institutional theory. In F. Maringe \& N. Foskett (Eds), Globalization and internationalization in higher education: Theoretical, strategic and management perspectives (pp. 65-80). London: Continuum.

Pillay, H., Watters, J., \& Hoff, L. (2013). Critical attributes of public-private partnerships: A case study in vocational education. International Journal of Adult Vocational Education and Technology, 4(1) 3145 .

Ryan, M. (2011) Improving reflective writing in higher education: A social semiotic perspective. Teaching in Higher Education, 16(1), 99-111.

Saldana, J. (2013). The coding manual for qualitative researchers (2nd ed.). London, UK: Sage.

Simons, H. (2009). Case study research in practice. Los Angeles CA: SAGE.

Stake, R. E. (1995). The art of case study research. Thousand Oaks CA: Sage Publications Inc.

Star, S. L., \& Griesemer. J. R. (1989). Institutional ecology, translations and boundary objects: Amateurs and professionals in Berkeley’s Museum of Vertebrate Zoology, 1907-39. Social Studies of Science, $19(3), 387-420$.

Stone, N. (2006). Conceptualising intercultural effectiveness for university teaching. Journal of Studies in international Education, 10(4), 334-356.

Watters, J., \& Deizmann. C. (2012). Mid-career professionals in STEM transitioning in school teaching: Barriers at the border. Paper presented at The Second International STEM in Education Conference. Beijing.

Yang, H., \& Silver, A. (2011). Enhancing transnational business teaching - An exploratory study of Australian academics' teaching experiences in Northeast People's Republic of China. In J. Zhou \& C. Clark (Eds.), Australia China Transnational Education (pp. 257-280). Shenyang, China: Liaoning University Press. 


\section{Appendix: Questionnaire}

\section{Survey Purpose:}

This survey is primarily interested in the institutional effects of International Doctoral Forum Partnerships rather than the personal effects. To this aim, the survey is framed by theory on boundary crossing mechanisms to help understand how the partnership is enacted. The survey is divided into four sections that align with the boundary crossing mechanisms, which include: identification; coordination; reflection; and transformation.

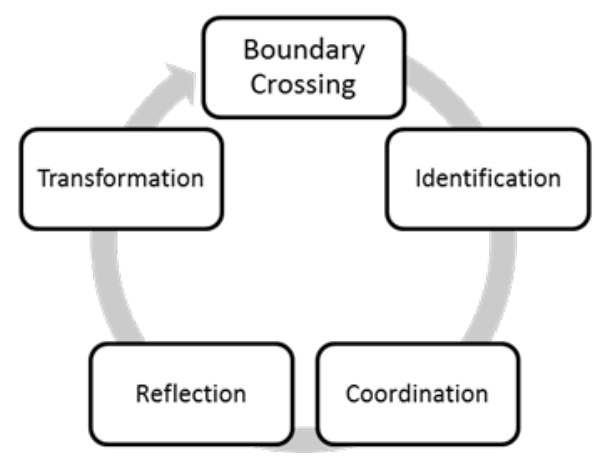

\section{Background Information}

- Your current academic status in this forum: Academic BNU, Doctoral student BNU, Academic QUT,Doctoral student QUT

- Your age: 18-25, 26-40, 41-55, 56-65, Over 65

- $\quad$ Your gender: Male, Female

- How many years have you been at this university?

For doctoral students:

- In which year did you start your doctoral study?

- In which year do you expect to complete your doctoral study?

For academics:

- How many doctoral students are you currently supervising?

- How many completed doctoral students have you supervised?

\section{Identification}

1. What do you think your university expects you to gain from this International Doctoral Forum Partnership?

2. What things do you think QUT and BNU might have in common, in terms of approaches to the International Doctoral Forum Partnership, and how do you think that they might differ?

3. What do you believe your university contributes to the partnership? 


\section{Coordination}

4. What strategies does your university use for coordinating the BNU-QUT International Doctoral Forum Partnership?

5. What 'boundaries' are you crossing in this International Doctoral Forum?

6. What challenges are you experiencing in crossing these boundaries?

7. Who and/or what is helping you to overcome these challenges?

\section{Reflection}

8. What new things have you learnt about your university or your partner university's coordination practices?

9. Describe how your doctoral forum experiences help you to understand the similarities and/or differences between your university and your partner university?

10. Can you describe a situation where QUT and BNU forum participants seemed to view the same forum event differently? Why do you think this was?

\section{Transformation}

11. How could the International Doctoral Forum Partnership lead to the creation of new practices or improvements to existing practices for your university?

[Note: Instructions on how to respond and spaces provided for responses and have been removed.] 


\section{Biographies}

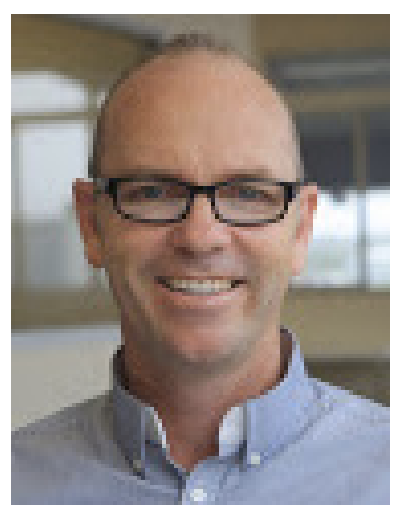

Dr Matthew Flynn is a Director at Well Grounded Consultancy with research interests in the innovative application of vocationalism, systems theory, and collaboration. Extensive real-world experience in vocational education in many industries provides him with a wellgrounded approach to his research.

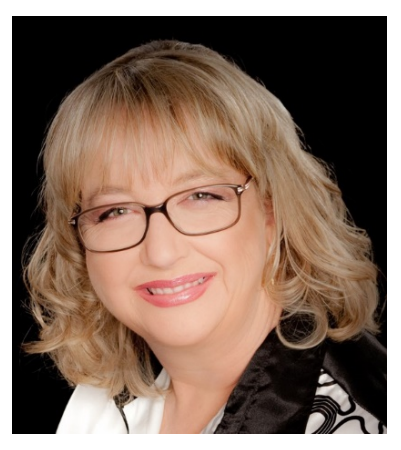

Dr Merilyn (Lyn) Carter (corresponding author) is an educational consultant in mathematics and numeracy, advising schools and providing professional development for teachers. She also works with the YuMiDeadly Centre at Queensland University of Technology, Brisbane, Australia, developing mathematics programs for indigenous and disadvantaged students. Her research interests include national standardized testing programs and literacy in mathematics. She draws on her experience as a teacher of mathematics to students in the secondary and primary years (for fifteen years) and in school management positions.

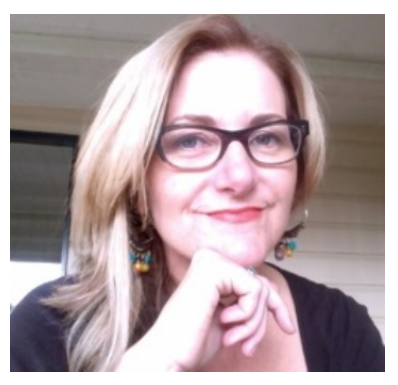

Dr Jennifer Alford is a Senior Lecturer in TESOL and English as a Second Language (ESL) studies in the Faculty of Education at Queensland University of Technology, Brisbane, Australia. Her research interests include applied linguistics, critical discourse analysis, and intercultural competence for teachers. She is currently working on a longitudinal research project that will investigate the academic transitions of ESL learners in Queensland metropolitan primary and secondary schools and the variables associated with increasing academic achievement.

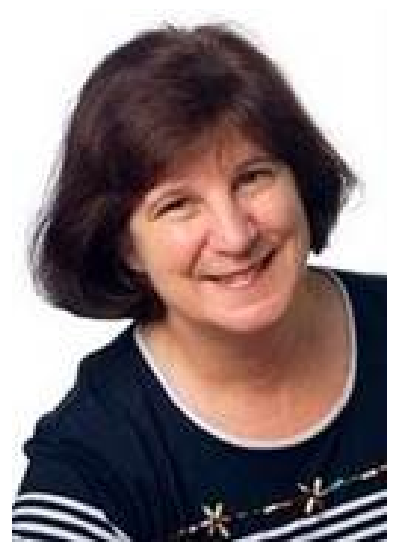

Dr Hilary Hughes is an Associate Professor in the Faculty of Education at Queensland University of Technology, Australia, where she teaches several Master of Education units. Her research interests include informed learning, learning space design, international student experience and teacher-librarianship. Hilary is an active member of QUT's Children and Youth Research Centre. She has received several learning and teaching awards and in 2010 was Fulbright Scholar-inResidence at the University of Colorado Denver. Hilary draws on previous experience as reference librarian and information literacy educator. 


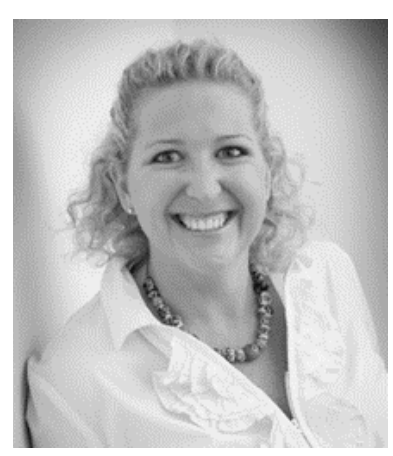

Dr Jillian Fox is a Senior Lecturer in the Faculty of Education at the Brisbane campus of Australian Catholic University. She lectures in the fields of early years mathematics, technology and pre-service teachers field experience. Jillian's research focuses on prior-to-school mathematics and teacher and parent impact on young children's mathematics. Current projects are exploring the nexus between digital technology and numeracy in the early years.

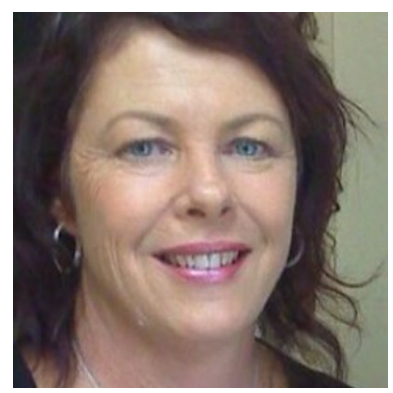

Dr Jennifer Duke worked in an Education Ministry for over 25 years as a teacher and school leader in early childhood, primary, secondary, general and special education contexts before becoming an academic. She is a lecturer is a lecturer in inclusive education in the Faculty of Education at Queensland University of Technology, Brisbane, Australia. Her research and teaching interests are in the area of Inclusive Education - Disability. 